\title{
Group Sales and Marketing in Convention Hotels
}

\section{Susan R. Gregory , Sheryl F. Kline \& Deborah Breiter}

To cite this article: Susan R. Gregory , Sheryl F. Kline \& Deborah Breiter (2005) Group Sales and Marketing in Convention Hotels, Journal of Travel \& Tourism Marketing, 18:1, 67-77, DOI: 10.1300/ J073v18n01 07

To link to this article: https://doi.org/10.1300/J073v18n01_07

曲 Published online: 10 Oct 2008.

Submit your article to this journal 준

Џlll Article views: 455

4 Citing articles: 6 View citing articles ๘ 


\title{
Group Sales and Marketing in Convention Hotels: Internet and Web Usage
}

\author{
Susan R. Gregory \\ Sheryl F. Kline \\ Deborah Breiter
}

\begin{abstract}
The goal of hotel sales and marketing is revenue generation. The methods employed by group sales and marketing professionals have evolved overtime to incorporate an array of technological innovations. The purpose of this research is to ascertain the perceptions that convention hotel sales and marketing professionals have about Internet and Web integration in the group sales process. The findings indicate that Internet and Web based marketing tools have become an integral part of hotel sales and marketing activities, though convention hotel managers do not necessarily attribute an increase in revenue to these activities. [Article copies available for a fee from The Haworth Document Delivery Service: 1-800-HAWORTH. E-mail address: <docdelivery@ haworthpress.com> Website: <http://www.HaworthPress.com> () 2005 by The Haworth Press, Inc. All rights reserved.]
\end{abstract}

KEYWORDS. Hotel, marketing, sales, technology, World Wide Web

\section{INTRODUCTION}

The Internet has become a necessary element in the marketing mix, making a traditional marketing effort more effective and efficient (Zeithaml \& Bitner, 2000). Giblin (2000) outlined five ways that the Internet would transform hotel sales, including changes in how requests for proposals would be handled; changes in communications between planners and convention services staff; the creation of a World Wide Web (WWW) based trading infrastructure for all players in convention and group business; the steady growth of application service providers; and a streamlined sales process. Jeong and Lambert (2001) cited the need for hotel companies to develop online marketing strategies that demonstrate three aspects of information quality, namely perceived usefulness; perceived ease of use; and perceived accessibility that help form attitudes towards the WWW. Gilbert and PowellPerry (2002), likewise, found that there is now widespread use of the WWW for electronic commerce and that hotel Web sites have a major advantage over other forms of communication media because of their interactivity and hence, can assist with the development of customer relationship management (CRM).

While the major goal of marketing, revenue management, has remained constant over time, the approach that marketing professionals take

Susan R. Gregory is Coordinator, Hotel Restaurant Management Program, Eastern Michigan University, Ypsilanti, MI 45197. Sheryl F. Kline is Assistant Professor and Director, Center for the Study of Lodging Operations, Department of Hospitality and Tourism Management, Purdue University, West Lafayette, IN 47907. Deborah Breiter is CFHLMA Professor, Convention \& Conference Management, Rosen School of Hospitality Management, University of Central Florida, Orlando, FL 32816.

Journal of Travel \& Tourism Marketing, Vol. 18(1) 2005 http://www.haworthpress.com/web/JTTM

(C) 2005 by The Haworth Press, Inc. All rights reserved. Digital Object Identifier: 10.1300/J073v18n01_07 
has evolved from transactional to relationship management to consultative. The development of e-commerce models that facilitate CRM and allow hotel sales professionals to act as consultants to their clients may have a positive effect on revenues. Overall, the possibility of interactivity through the medium of the WWW has created an unprecedented marketing opportunity (Hoffman \& Novak, 1996).

The purpose of this research was to ascertain the perceptions that convention hotel sales and marketing professionals have about their hotel Web sites as marketing tools for selling to the group market and provide some needed empirical evidence of the impact of Web marketing in the hotel industry. Specifically, the research addresses the following objectives:

1. Describe the perceptions that marketing professionals in top tier convention hotels have regarding e-marketing activities.

2. Compare usage and effectiveness of traditional marketing and e-marketing activities in top tier convention hotels in the United States.

3. Identify the types of interactive and noninteractive Web site marketing features of top tier convention hotels in the United States.

\section{REVIEW OF THE LITERATURE}

\section{Innovation}

Acquisitions and mergers dominated the hotel industry in the 1990s, with the seven largest hotel companies eventually owning 59 brands (AHLA, 2002). Many of these companies are publicly traded and under increasing pressure to perform for their investors. This pressure has demanded that hotels innovate, adapt or die. Business executives in all sectors of the United States economy believed that innovation would be the prime ingredient of continued growth and profits (Sheth \& Ram, 1987). Technology innovation for business and industry throughout the 1990s and the new millennium has focused in large part on the development of the Internet and WWW.
Integrating the Internet into every facet of the business is considered by some the way to stay competitive (Hamm, Welch, Zellner, Keenan \& Engardio, 2002). AMR Research surveyed corporate executives and found that $87 \%$ would either sustain or increase their spending on the Internet initiatives for sales growth and customer management and 84\% will increase their online purchasing ability (Hamm et al., 2002). The importance of the WWW as a commercial medium, as well as a marketing environment, requires a rethinking of traditional marketing concepts, particularly in terms of the ability of the WWW to influence experiential and goal-directed behaviors (Hoffman \& Novak, 1996). Murphy (1999), building on the works of Hoffman and Novak and Rogers' theories of innovation examined the clicking behavior of surfers and searchers (his version of experiential and goal-directed behaviors) who visited hotel Web sites. Other researchers in the hospitality and tourism field have also addressed ways in which the WWW challenges marketing professionals in their pursuit of greater market shares and other improved business results (De Ruyter,Wetzelf \& Kleijnem, 2000; Rust \& Lemon, 2001;Van Riel, Liljader \& Jurriens, 2001).

\section{Hotel Sales Technology Application}

The Internet has had a significant impact on competition in the lodging industry (Jeong \& Lambert, 2001). By 1998, virtually all respondents to a technology survey mailed to global hoteliers reported using the Internet in business (Van Hoof, Ruys, \& Combrink, 1999). It was reported in 1999 that hotels had embraced the WWW early in the decade (O'Connor and Horan, 1999). The Internet has revolutionized the whole business structure of the lodging industry by offering an interactive marketing system (Jeong \& Lambert, 1999).

Evolving technology is affecting how industry relates to, communicates with and serves business customers who are looking for convenience that enhances their productivity (Blank, 1999). But selling products and services on-line is only one service. Providing e-service is beginning to generate a great deal of interest (De Ruyter, Wetzelf \& Kleijnem, 2000; Rust \& Lemon, 2001; VanRiel, Liljader \& Jurriens, 2001) since e-service can 
provide experiences and personalization for consumers that ultimately increase revenues and profits. Understanding the theory of planned behavior and its application to the WWW has become important in understanding how consumers will be influenced by the WWW and consequently choose to purchase products and services offered on the WWW or not (Vanucci \& Kerstetter, 2001; Wolin, Korgaonkar \& Lund, 2002).

Much of the research into Internet usage in the hospitality and tourism industry has been from the perspective of hospitality and tourism marketing entities, both public and private, and their efforts to attract individual travelers. Hanna and Millar (1997), for example, detailed the early use of the Internet by destinations to provide photographs, tourist information and events calendars and other travel planning information. They suggested that the demand for tourism promotion on the Internet would most certainly increase. An individual's search for tourism-related information may be ideally suited for the Internet and a variety of tourism-related businesses and services in a destination could work together to create virtual tourism communities on the WWW, creating a synergistic effect (Palmer \& McCole, 2000). Data from Georgia Tech's World Wide Web 1997 survey found that searching online and purchasing individual travel online was one of the many consumer trends in the marketplace (Weber \& Roehl, 1999). A study designed to measure the effectiveness of a state tourism Web site discovered that individual travel plans were in fact influenced by the site (Tierney, 2000). It was found that hoteliers in Colorado relied on the WWW to generate individual reservation inquiries (Gregory and Breiter, 2001a). Weilbaker and Crocker (2002) noted that most online purchases of hotel rooms are for leisure and individual travelers. Clearly, the effect that WWW marketing has had on individuals has been investigated extensively and found to be critical to hospitality businesses and tourism destinations.

As hospitality businesses embrace CRM and consultative selling, their Web sites may need to evolve from the traditional online presence that offered very little interactivity. Gilbert and Powell-Perry (2002) expanded Gilbert's (1996) 5-stage model for the devel- opment of CRM to include Web activities ranging from on-line questionnaires to help in the first stage (identification) to on-line member benefits that would increase customer retention (the fifth stage). Similarly, Murphy, Hofacker and Bennett (2001) generalized potential strategies for Web site marketing activities such as selling online that would include interactive components.

The extent to which hotels have been using interactive Web features has been studied by different researchers. Van Hoof et al. (1999) surveyed hotels around the world and found that although almost $90 \%$ of them had Web pages, only one in four offered availability information or virtual tours. Gilbert and PowellPerry (2002) noted a significant increase in interactive features such as real-time processing of reservations, on-line availability, on-line enrollment into loyalty programs, and on-line searches over a two-year time period.

Hotels can benefit from these types of Web interactive features in a variety of ways. For example, making electronic forms and email available to WWW users takes full advantage of the WWW's ability to engage the site visitor and get them involved with the property, a first step in the booking process (Gilbert \& Powell-Perry, 2002). A hotel's Web site, furthermore, may provide information and interactivity features that can help meeting planners perform their jobs more efficiently. This is particularly important in light of a supplement to the May, 2002 issue of Convene, the Journal of the Professional Convention Management Association, which reported that meeting planners are using Internet based site research more than any other technology except for email. Plog Research (2000) found that $51 \%$ of association meeting planners and $63 \%$ of corporate meeting planners responding to their survey were using the Internet to search for facilities. Both types of planners in this study reported varying degrees of generating online Requests for Proposals (RFP), transmitting contracts online and having their own meeting Web sites.

Trade show managers have reported significant Internet usage of Web based services for both attendees and exhibitors but not for conducting business with hotels (Gregory \& Breiter, 2001b). Though trade show managers 
in this study who wanted to increase their overall communications through the Internet also indicated a desire to increase communications with hotels and housing bureaus in particular (Gregory \& Breiter, 2001b).

Even though some planners believe the Internet offers benefits to them, barriers to usage might include things like lack of training or the time necessary to become familiar with the new technology (Vanucci \& Kerstetter, 2001). Other reasons that planners may be not be using the WWW for more aspects of their jobs is that most Web sites do not have the ability to allow booking online, according to Rousseau:

Planners can submit their RFPs online, but it's still hotel salespeople, not computers, who check to see if space is available on the desired dates (often in less than 24 hours, but not instantly). And then there's the sticky matter of rates. Planners indicate the range they expect to pay in the RFP, but the actual dollar amount is hammered out in person-to person conversations. (2001, p. 8)

While this trend may be changing, with both hotel Web sites and search sites like GetThere and DirectMeetings offering realtime, live booking capabilities for groups, it is only small groups that will be able to take advantage of this new WWW interactivity (Rousseau, 2001).

Perhaps the full potential of hotel Web marketing has not yet been realized because of the lack of interactivity that can be accommodated in the present technological environment. It also remains to be seen that Web marketing can replace some of the more traditional hotel marketing activities that have been developed through customer relationship and consultative techniques. The research presented here helps shed some light on these issues.

\section{METHODOLOGY}

\section{The Instrument}

The survey instrument for this study was developed using the Delphi Method and adaptation of an instrument previously used in re- search on trade show and convention management technology usage. The Delphi Method provides a way to structure group communications in an effective and efficient manner (Adler \& Ziglio, 2000). Gregory and Breiter (2001b) developed and tested a survey instrument to assess trade show and convention management technology adaptation and usage. The survey instrument used in the research reported in this paper adapted questions related to demographic profile and technology usage. Additional questions were included that sought to uncover the level of interactive and non-interactive Web features related to hotel marketing and sales activities. Items were not identified as being interactive or non-interactive but were included in a comprehensive list of Web site features that might be offered by convention hotels. Questions about non-Web marketing and sales activities were also posed for purposes of comparing an array of marketing methods.

\section{The Sample}

Tradeshow Week annually publishes a listing of the major exhibit halls in the United States and Canada. The 24th annual edition (2001) contained statistics on exhibit halls in hotels in the United States, listing 71 hotels with dedicated exhibit space of 25,000 square feet or more. This population was chosen for the study with the assumption that the major convention hotels would have the most advanced Web sites in terms of the features and benefits offered to meeting planners.

\section{Data Collection}

A modified Dilman (1978) approach, using multiple exposures to potential respondents was used in data collection. A postcard was sent to the target population followed by two mailed survey instruments. A postage paid business reply envelope was provided for each survey in each mailing. Phone calls were then made to non-respondents and permission was asked to fax the survey to their attention for immediate completion and return. They could fax their responses or use surface mail to return the surveys. 


\section{Data Analysis}

Returned surveys were entered into a SPSS Base 10.0 (1999) statistical software program. Statistical frequencies were calculated to identify measures of central tendency. Paired t tests and cross tabs were run to determine response differences based on demographic variables and technology usage.

The population for this study was 71 large convention hotels in the United States as identified by the Tradeshow Week Major Exhibit Hall Directory 24th annual edition (2001). This list includes hotels with dedicated exhibit halls of at least 25,000 square feet. The population size $(\mathrm{n}=71)$ was small and subsequently the response number is small $(\mathrm{n}=21$ or $30 \%$ ). This appears to be a low response rate yet it is higher than previous technology studies that had an average response rate of 18.4\% (Van Hoof et al., 1999). It should be noted that limitations exist both with respect to generalizability to the full population of hotels that market to groups, as well as with respect to the choice of statistical techniques used for analysis. Due to the limited size of the population and small sample size in this study, only descriptive statistics were analyzed.

\section{RESULTS AND DISCUSSION}

\section{Sample Description}

The top tier convention hotels in the United States were identified by meeting room and exhibit space. The average square footage of total meeting and exhibit space offered by the respondents is 132,040 square feet. The total square footage of meeting space ranged from 14,000 square feet to 380,000 square feet. The average number of meeting rooms of the responding hotels is 39.9 and the average size of the largest meeting room is 36,514 square feet. The number of meeting rooms ranges from 10 to 75 per property. The largest meeting rooms in these hotels range in size from 6,900 to 89,400 square feet.

The dedicated exhibit space ranged from 25,000 to 180,000 square feet. The minimum number of square footage for the population was 25,000 and therefore the sample includes one property at the lowest limit. The mean for the dedicated exhibit space is 51,475 square feet.

This study requested information about total group sales revenue generated in the year 2001. Most respondents were reluctant to answer this question. Only 8 out of 21 surveys included a dollar amount for this question. Several managers wrote that they were not permitted to share this information. The revenues ranged from a low of $\$ 12$ million to a high of $\$ 45$ million. The average group sales revenue for the reported dollar amount is $\$ 28.5$ million U. S. dollars. This figure cannot be considered to be representative of the sample due to the very low response rate for this question.

The average number of guest rooms per property is $1,281.8$. The guest rooms numbers range from a low 196 rooms to a high of 3,174. The average percentage of guest rooms committed to group sales is $66.8 \%$. More information about these results is located on Table 1.

\section{Respondent Demographics}

The hotel sales and marketing managers in the sample are profiled by the demographic characteristics of gender, level of education, years in the business and years in the current position. The managers' titles were also ascertained. More females (62\%) responded than (38\%) males. The mean and majority $(62 \%)$ of managers attained a bachelor's degree. The level of education ranged from some high school education to the completion of a graduate degree. The titles for the respondents ranged from Vice President of Marketing to the Director of Sales. The majority (47.6\%) of the respondents were Directors of Sales and Marketing. This is not surprising since the surveys were directed to the person holding that position. The second largest group (33.3\%) was Director of Sales.

The managers also provided information about how long they have worked in hotel sales and marketing and how long they have held their current position. This is a well-seasoned group of managers that have been in the business for a long time. The mode of response for this question was for over 16 years 
TABLE 1. Characteristics of Hotel Properties

\begin{tabular}{|c|c|c|c|}
\hline Sq. Ft. & Frequency & Percent & Mean \\
\hline & & & 132,040 \\
\hline $14,000-70,000$ & 6 & 28.5 & \\
\hline $100,000-180,000$ & 11 & 52.4 & \\
\hline $200,000-380,000$ & 4 & 19.1 & \\
\hline \multicolumn{3}{|c|}{ Number of Meeting Rooms } & 39.9 \\
\hline 10 to 18 & 4 & 19 & \\
\hline 20 to 35 & 5 & 24 & \\
\hline 42 to 55 & 9 & 43 & \\
\hline 68 to 75 & 3 & 14 & \\
\hline Sq. Ft. & & & $36,514.3$ \\
\hline 6,900 to 1,900 & 5 & 24 & \\
\hline 25,000 to 38,000 & 8 & 38.1 & \\
\hline 40,000 to 70,000 & 7 & 33.3 & \\
\hline 89,400 & 1 & 4.6 & \\
\hline \multicolumn{4}{|c|}{ Square Footage of Dedicated Exhibit Space Per Property } \\
\hline Sq. Ft. & & & 51,475 \\
\hline 2,500 to 39,500 & 7 & 33.4 & \\
\hline 40,000 to 70,000 & 11 & 52.4 & \\
\hline 80,000 to 180,000 & 3 & 14.2 & \\
\hline \multicolumn{3}{|l|}{ No. of Guest Rooms } & $1,281.8$ \\
\hline 196 to 600 & 6 & 28.5 & \\
\hline 1,013 to 1,878 & 11 & 52.5 & \\
\hline 2,019 to 3,174 & 4 & 19 & \\
\hline \multicolumn{3}{|c|}{ Percentage of Rooms used for Convention } & 66.8 \\
\hline 22 to $40 \%$ & 3 & 14.3 & \\
\hline 50 to $70 \%$ & 8 & 38.1 & \\
\hline 80 to $90 \%$ & 6 & 28.6 & \\
\hline
\end{tabular}

$N=21$

but the mean was for 13 to 15 years. The minimum number of years was 4 to 6 .

Tenure in their respective current positions is much shorter than the number of years spent in the field. This is quite typical for the hotel industry. The mean for how long the managers have held their current positions is between 4 to 6 years. The longest a respondent has been in his/her current position is over sixteen years and the shortest time anyone has held a current position is less than one year. See Table 2.

\section{World Wide Web Usage and Importance}

How long have these managers been using the WWW for performing their job responsibilities? The respondents on average have
TABLE 2. Respondents Demographic Profile

\begin{tabular}{|c|c|c|c|}
\hline Level of Education & Frequency & Percent & Mode \\
\hline Some high school & 1 & 4.8 & \\
\hline $\begin{array}{l}\text { Some college or vocational } \\
\text { School }\end{array}$ & 3 & 14.3 & \\
\hline Bachelor's degree & 13 & 61.9 & $x$ \\
\hline Some graduate credits & 2 & 9.5 & \\
\hline Graduate degree & 2 & 9.5 & \\
\hline \multirow[t]{2}{*}{ Years Worked in Hotel } & Frequency & Percent & Mean \\
\hline & & & 6.0 \\
\hline 1 to 6 years & 1 & 4.8 & \\
\hline 7 to 9 years & 2 & 9.5 & \\
\hline 10 to 12 years & 3 & 14.3 & \\
\hline 13 to 15 years & 5 & 23.8 & \\
\hline Over 16 years & 10 & 47.6 & \\
\hline \multirow[t]{2}{*}{ Years in Current Position } & Frequency & Percent & Mean \\
\hline & & & 3.24 \\
\hline Less than 1 year & 3 & 14.3 & \\
\hline 1 to 3 years & 8 & 38.1 & \\
\hline 4 to 6 years & 2 & 9.5 & \\
\hline 7 to 9 years & 3 & 14.3 & \\
\hline 10 to 12 years & 1 & 4.8 & \\
\hline 13 to 15 years & 2 & 9.5 & \\
\hline Over 16 years & 2 & 9.5 & \\
\hline
\end{tabular}

been using the Web for 2.76 years. To put this in perspective, these managers have been using the WWW on the job for $25 \%$ of their tenure as sales and marketing professionals. This usage has been most recent and the majority of managers began and developed their careers prior to the advent of the Internet as a sales and marketing tool. This group of relatively new users perceives the importance of the Internet. The mean response indicates that these sales and marketing professionals rate the use of the Internet as an important part of their job responsibilities. The next most frequent response was that the Internet was perceived as most important. See Table 3.

\section{Satisfaction with Web Based Sales Issues}

The research evaluated the perception of satisfaction with Web based issues including the satisfaction with the group sales portion of the Web site, the hotel's commitment to Web 
Gregory, Kline, and Breiter

TABLE 3. Perception of Internet Usage

\begin{tabular}{|c|c|c|c|}
\hline $\begin{array}{l}\text { Length of Time the Managers } \\
\text { Used the Internet for Work }\end{array}$ & Frequency & Percent & Mean \\
\hline & & & 2.76 \\
\hline 1 to 3 years & 10 & 47.6 & \\
\hline 3 to 5 years & 6 & 28.6 & \\
\hline More than 5 years & 5 & 23.8 & \\
\hline \multirow[t]{2}{*}{$\begin{array}{l}\text { Importance of Internet for } \\
\text { Job Responsibilities }\end{array}$} & Frequency & Percent & Mean \\
\hline & & & 4.0 \\
\hline Extremely Unimportant & 1 & 4.8 & \\
\hline Unimportant & 1 & 4.8 & \\
\hline Neither Important or Unimportant & 1 & 4.8 & \\
\hline Important & 10 & 47.6 & \\
\hline Extremely Important & 6 & 28.6 & \\
\hline
\end{tabular}

based sales and marketing activities and Web based sales and marketing training. A fivepoint Likert Scale was used with $1=$ very unsatisfied and $5=$ very satisfied. The highest mean was 3.90 for the hotel's commitment to Web based sales and marketing activities. This next highest mean is 3.57 for the perception of Web based training and the perception of the Web sites' group sales and marketing section is 3.15. See Table 4.

\section{Group Sales and Marketing Activities}

A list of 13 typical group sales and marketing activities was presented and respondents were asked two questions for each item. The first related to the activities' effectiveness in reaching potential group business. The second question related to how often this activity was used in the past 12 months by sales managers. The activities were: Personal Sales Calls, Sales Prospecting, Sales Blitz, Referral Program, Trade Show Booth, Efforts with CVB, Familization Trips, Property Web site, Direct Mail, Corporate Web site, E-Mail Blasts, Efforts with Convention Center, and Fax Blasts.

The Web based activities include "Property Web site," "Corporate Web site," and "E-mail blasts." Those activities rank from a mean of 3.55 to 3.25 and are viewed as neither effective nor ineffective by the respondents. The
TABLE 4. Perception of Internet Usage

\begin{tabular}{|c|c|c|c|}
\hline $\begin{array}{l}\text { Level of Satisfaction with } \\
\text { Group Sales Section of } \\
\text { Website }\end{array}$ & Frequency & Percent & Mean \\
\hline & & & 3.15 \\
\hline Very Dissatisfied & 2 & 9.5 & \\
\hline Dissatisfied & 2 & 9.5 & \\
\hline Neither Satisfied or Dissatisfied & 8 & 38.1 & \\
\hline Satisfied & 7 & 33.3 & \\
\hline Very Satisfied & 1 & 4.8 & \\
\hline \multirow[t]{2}{*}{$\begin{array}{l}\text { Level of Satisfaction with } \\
\text { Hotel's Commitment to } \\
\text { Web Based Sales and } \\
\text { Marketing Activities }\end{array}$} & Frequency & Percent & Mean \\
\hline & & & 3.90 \\
\hline Very Dissatisfied & 0 & 0 & \\
\hline Dissatisfied & 2 & 9.5 & \\
\hline Neither Satisfied or Dissatisfied & 5 & 23.8 & \\
\hline Satisfied & 7 & 33.3 & \\
\hline Very Satisfied & 7 & 33.3 & \\
\hline \multirow[t]{2}{*}{$\begin{array}{l}\text { Level of Satisfaction with Web } \\
\text { Based Sales and Marketing } \\
\text { Training Provided by the } \\
\text { Company }\end{array}$} & Frequency & Percent & Mean \\
\hline & & & 3.57 \\
\hline Very Dissatisfied & 0 & 0 & \\
\hline Dissatisfied & 2 & 9.5 & \\
\hline Neither Satisfied or Dissatisfied & 8 & 38.1 & \\
\hline Satisfied & 8 & 38.1 & \\
\hline Very Satisfied & 3 & 14.3 & \\
\hline
\end{tabular}

higher means are provided for the 7 non-Web based sales activities. These items traditionally have high levels of personal involvement by the sales and marketing professional. Webbased sales and marketing activities have a lower level of personal interaction and are also newer methods used for reaching potential group business.

Those same 7 non-Web based activities are also rated as the ones used the most frequently in the past 12 months. However, the order is slightly different, with sales blitzes occurring less frequently, yet being viewed as effective. As for the Web based activities, the Property Web site mean for frequency of use is 3.9 and that is slightly higher than the mean (3.55) for the perception of this activities effectiveness. Also, e-mail blasts were not frequently used 
(2.94) but were valued slightly higher in perception of effectiveness (3.25). See Table 5.

\section{Web Site Features}

In Table 6, the 15 Web site features are listed from most frequently found to least frequently found on a hotel property Web sites. Only one hotel did not have its own Web site but did have a corporate Web site that included many of these features. Only one feature is found on all the Web sites and that is a "Meeting Capacity Charts" area. The feature found the least is a "Link to Public Web Site." The most frequently used interactive features were "Ability to E-Mail Sales Department" (90\%) and "OnLine Room Reservations Capability" (86\%).

TABLE 5. Sales and Marketing Activities On and Off the Web

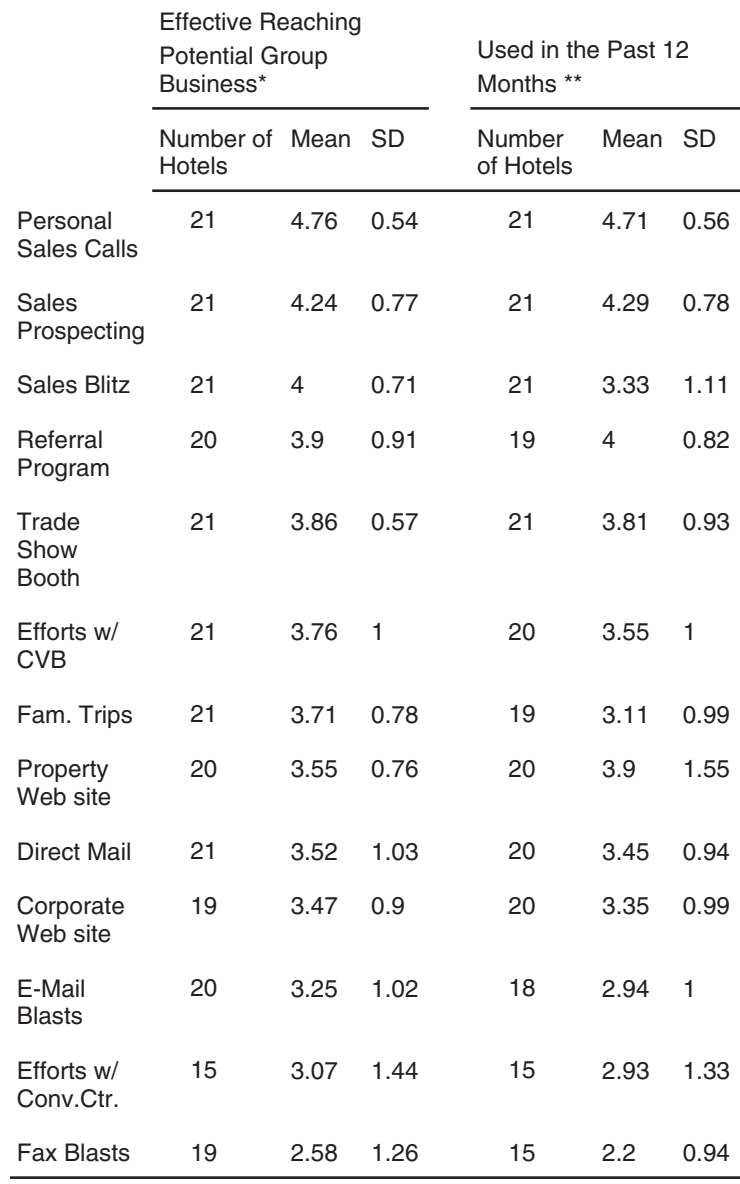

Likert Scale: $0=$ Do Not Use At All, $5=$ Very Effective ${ }^{*}$ or Very Frequently ${ }^{\star \star}$ $\mathrm{N}=21$
TABLE 6. Hotel Property Web Site Features $(\mathrm{N}=$ 21

\begin{tabular}{lcc} 
Features of the Web site & Frequency & Percent \\
\hline Meeting Capacity Charts & 21 & 100 \\
Hotel Information & 20 & 95 \\
Ability to E-Mail Sales Department* & 19 & 90 \\
On-Line Room Reservation Capability* & 18 & 86 \\
Reservation Information & 16 & 76 \\
PDF Files & 14 & 67 \\
Dedicated Space for Meeting Planners & 14 & 67 \\
Ability to Submit RFP On-Line* & 12 & 57 \\
Floor Plans to Scale & 10 & 48 \\
Virtual Tour* & 10 & 48 \\
Link to CVB $^{*}$ & 9 & 43 \\
Ability for Meeting Planner to Book & 9 & 43 \\
On-Line* & & 10 \\
Link to Convention Housing Provider* $_{\text {Link to Public Web site (mpoint.com, }}^{*}$ & 3 & 14 \\
starcite.com) & 2 & 5 \\
Do Not Have Own Web site & & \\
\hline
\end{tabular}

* $=$ Interactive function

These types of features are also used for the transient market. The other interactive features listed are for group business. These features range from "Ability to Submit RFP On-Line" at $57 \%$ to "Link to Public Web site" at $10 \%$ of Web sites. The group portion of the Web site features favors a non-interactive, fact sheet style presentation of information. See Table 6 .

\section{Impact of Web Site on Performance Measures}

The top two performance measures were "Occupancy Percentage" (3.21) and "RevPar" (3.00). The other measures had means from 2.95 to 2.89 . The implications are that the perception of the Web site impact on performance measures is at best "neither increase nor decrease." At worst the impact decreases performance measures. See Table 7.

\section{DISCUSSION}

Traditional hotel sales and marketing activities have been affected by the Internet and 
TABLE 7. Impact of Web Site on Hotel Performance

\begin{tabular}{lcc} 
Performance Measures & N & Mean \\
\hline Occupancy Percentage & 19 & 3.21 \\
RevPar & 18 & 3.00 \\
Group Room Rates & 19 & 2.95 \\
Number of Group Room Nights & 19 & 2.95 \\
Average Daily Rate & 19 & 2.89 \\
\hline
\end{tabular}

Likert Scale: 1 = Significantly Decreased, 5 = Significantly Increased

Web. Technology may assist convention hotel sales managers in managing revenue, information, communications and services. Web based marketing technology is unique in that it offers an interactive platform for sales and marketing professionals and their customers to conduct business. Interactive technology provides a means of information to flow from the source, the hotel Web site, to potential clients and from these same potential clients to the hotel Web site. Non-interactive technology provides descriptions and listing of services offered but no means of two-way communications. Both forms of technology perform important functions in the selling of convention hotels and their services. How convention sales and marketing professionals perceive and integrate these functions into their activities may have a significant impact on how they compete with other large convention hotels.

The Web sites of the hotels in this study offered both interactive and non-interactive features. Examples of interactive features specific to group meeting professionals are: ability for meeting planner to book on-line; ability to submit RFP on-line; link to convention housing provider; link to public Web site (mpoint.com, starcite.com). The non-interactive features include: meeting capacity charts, hotel information; floor plan to scale. The interactive features were underutilized with less than half of the hotels choosing to provide interactive features that meeting planners have indicated are important. At the same time, Gregory and Breiter's (2001b) study of trade show managers showed that they wanted the ability to increase their usage of the Internet to conduct business with convention hotels and housing bureau.
Convention hotels group sales managers' report that they use technology in the performance of their job but do not perceive that technology alone increases hotel occupancy and sales. The results of this research indicate that convention hotel sales and marketing professionals view technology almost as ancillary to reaching these properties' performance measures. They report that the traditional sales and marketing activities are effective in reaching potential group markets and at the same time are pleased with the level of commitment to their hotel's Web sales and marketing activities. The Web based sales tools that provide two-way communications are currently seen as "necessary" to have but not a means of conducting business that they rely on. Currently Web technology cannot effectively negotiate date, rates and function space with meeting professionals. The specifications for a group contract can be complex and multifaceted requiring tangible and intangible information that current Web technology cannot capture. Respondents in this study tended to be older and thus more likely to have learned the sales and marketing skills prior to Web based technology innovations.

Further research may find that the Web based sales and marketing activities are more effective and efficient in meeting performance measures for the transient market. In a limited study, Gregory and Breiter (2001a) found that Web based technology was effective in communicating to the individual traveler. Replication of both studies on a larger scale may provide a comparison between group and transient markets in increasing performance measures using Web based technology.

Technology has had a profound impact on the way convention hotels conduct their sales and marketing functions. This impact is pervasive throughout the sales stages. This limited study did not confirm the effectiveness of Web based technology for increasing performance measures. This may indicate that convention hotel sales managers would attribute increased group market average daily and occupancy percentages to their own sales efforts. It remains to be seen how effective technology is in reaching convention hotel performance goals. 


\section{REFERENCES}

Adler, J., \& Ziglio, E. (2000). Gazing into the oracle: The Delphi method and its application to social policy and public health. London: Kingsley Publishers.

American Hotel \& Lodging Association (AHLA), Information Center (2002). Top 50 hotel companies, Retrieved January 17, 2002 from http://www. ahlaonline.org/infocenter/top50.asp

Blank, D. (September 6, 1999). Paradigm shift, Hotel Motel Management, 214(15) 36-38.

Convene (May 2002). Journal of the Professional Convention Management Association.

De Ruyter, K., Wetzels, M., \& Kleijnen, M. (2000). Customer adoption of e-service: An experimental study. International Journal of Service Industry Management, 12(2), 184-207.

Dilman, D. (1978). Mail and telephone surveys. New York: John Wiley \& Sons.

Giblin, S. (2000). Five ways the Internet will transform the hospitality industry in the next six months. The Bottomline, 15(1), 6-8.

Gilbert, D. (1996). Relationship marketing and airline loyalty schemes. Tourism Management, 17(8), 575582.

Gilbert, D., \& Powell-Perry, J. (2002). Exploring developments in Web based relationship marketing within the hotel industry. Journal of Hospitality \& Leisure Marketing, 9(3/4), 141-159.

Gregory, S., \& Breiter, D. (2001a). Leveling the playing field: E-marketing's impact on lodging operations. Journal of Hospitality \& Leisure Marketing, 7(4), 45-50.

Gregory, S., \& Breiter, D. (2001b). Trade show managers: Profile in technology usage. Journal of Convention \& Exhibition Management, 3(3), 63-76.

Hamm, S., Welch, David, Zellner, W., Keenan, F., \& Engardio, Peter (2002). E_BIX: Down but hardly out. BusinessWeek, March 26, 2002. 126-130.

Hanna, J.R.P., \& Millar, R.J. (1997). Promoting tourism on the Internet. Tourism Management, 18(7), 469470.

Hoffman, D.C. \& Novak, T.P. (1996). Marketing in hypermedia computer-mediated environments: Conceptual foundations. Journal of Marketing (60), 3, $50-69$.

Jeong, M., \& Lambert, C. (1999). Measuring the information quality on lodging Web sites. International Journal of Hospitality Information Technology, 1(1), 63-76.

Jeong, M., \& Lambert, C. (2001). Adaptation of an information quality framework to measure customer behavior intentions to use lodging Web sites. International Journal of Hospitality Management, 20(2): 129-46.
Murphy, J. (1999). Surfers and searchers: An examination of Web-site visitors' clicking behavior. Cornell Hotel and Restaurant Administration Quarterly, 40(2), 84-95.

Murphy, J., Hofacker, C.F. \& Bennett, M. (2001). Website-generated market-research data. Cornell Hotel and Restaurant Administration Quarterly, 42(1), 82-91.

O’Connor, P., \& Horan, P. (1999). An analysis of Web reservation facilities in the top 50 international hotel chains. International Journal of Hospitality Information Technology, 1(1), 77-86.

Palmer, A., \& McCole, P. (2000). The role of electronic commerce in creating virtual tourism destination marketing organizations. International Journal of Contemporary Hospitality Management, 12(3), 198204.

Plog Research (2000). Meetings \& Conventions Magazine's 2000 meetings market study (26-3747), New York: Cahners Business Information.

Rousseau, B. (2001). Adapting to a Web future. Successful Meetings, 2001 (September). Supplement entitled Meeting planners' guide to using the Web, p. 4 and 8.

Rust, R.L., \& Lemon, K.N. (2001). E service and the consumer. International Journal of E Commerce, 5(3), 85-101.

Sheth, J., \& Ram, S. (1997). Bringing innovation to market: How to break corporate and customer barriers. John Wiley and Sons, NY.

SPSS Base 10.0 (Computer software). Chicago, IL: SPSS, Inc.

Tierney, P. (2000). Internet-based evaluation of tourism Web site effectiveness: Methodological issues and survey results. Journal of Travel Research, 39, 212-219.

Tradeshow Week (2001, August). Major Exhibit Hall Directory, 24th annual edition. Los Angeles.

Van Hoof, H.B., Ruys, H.F., \& Combrink, T.E. (1999). Global hoteliers and the Internet: Use and perceptions. International Journal of Hospitality Information Technology, 1(1), 45-62.

VanRiel, A.C.R., Liljander, V., \& Jurriens, P. (2001). Exploring consumer evaluations of e-services: A portal site. International Journal of Service Industry Management, 12(4), 359-377.

Vanucci, C.L., \& Kerstetter, D.L. (2001). Meeting planners' use of the Internet to plan group meetings. Journal of Convention \& Exhibition Management, 2(4), 23-36.

Weber, K., \& Roehl, W.S. (1999). Profiling people searching for and purchasing travel products on the World Wide Web. Journal of Travel Research, 37, 291-298.

Weilbaker, D.C., \& Crocker, K. (2002). The importance of selling abilities in corporate hospitality sales for 
corporate customers. Journal of Hospitality and Leisure Marketing, 9(3/4), 51-66.

Wolin, L.D., Korgaonkar, P., \& Lund, D. (2002). Beliefs, attitudes and behaviours towards Web advertising. International Journal of Advertising, 21, 87-113.

Zeithaml, A., \& Bitner, M. (2000) Services Marketing: Integrating customer focus across the firm. Irwin McGraw-Hill, Madison, WI.
SUBMITTED: June 20, 2002

FIRST REVISION: May 25, 2003

SECOND REVISION: September 24, 2003

THIRD REVISON: March 25, 2004

ACCEPTED: April 2, 2004

REFEREED ANONYMOUSLY

For FACULTY/PROFESSIONALS with journal subscription recommendation authority for their institutional library . . .

If you have read a reprint or photocopy of this article, would you like to make sure that your library also subscribes to this journal? If you have the authority to recommend subscriptions to your library, we will send you a free complete (print edition) sample copy for review with your librarian.

1. Fill out the form below and make sure that you type or write out clearly both the name of the journal and your own name and address. Or send your request via e-mail to docdelivery@ haworthpress.com including in the subject line "Sample Copy Request" and the title of this journal.

2. Make sure to include your name and complete postal mailing address as well as your institutional/agency library name in the text of your e-mail.

[Please note: we cannot mail specific journal samples, such as the issue in which a specific article appears. Sample issues are provided with the hope that you might review a possible subscription/e-subscription with your institution's librarian. There is no charge for an institution/campus-wide electronic subscription concurrent with the archival print edition subscription.]

$\square$ YES! Please send me a complimentary sample of this journal:

(please write complete journal title here-do not leave blank)

I will show this journal to our institutional or agency library for a possible subscription. Institution/Agency Library:

Name:

Institution:

Address:

City: __ State: __ip:

Return to: Sample Copy Department, The Haworth Press, Inc., 10 Alice Street, Binghamton, NY 13904-1580 